\title{
INTRODUCTION
}

\section{The Role of Armed Forces in Homeland Security: European and American Experiences and Practices}

\author{
Dr. John L. Clarke*
}

Homeland security is a topic that has generated a great deal of attention in the past five years, on both sides of the Atlantic. With the increased focus on the homeland, or domestic, security of states in the aftermath of the terrorist attacks on New York, Washington, and Madrid, senior officials have been challenged to provide adequate levels of domestic security consistent with the resources that advanced Western states have available for these purposes.

States have been hard pressed to develop and equip security forces that will be able to perform the tasks required to maintain a high level of homeland security. In many instances, leaders have looked to the military to carry out these key missions.

Military forces bring many advantages to these challenges. They are usually well organized, mobile, and well equipped. In many countries, there is a tradition of using military forces in support of civil authorities, a tradition that can be expanded to include a broad range of homeland security tasks.

However, military forces are normally trained for missions that are quite different from those necessary for achieving effective homeland security. This is particularly true with regard to the use of force. While law enforcement officers are trained to use force as a last resort, soldiers are trained to use it in the first instance.

As a consequence, while the temptation to employ existing military forces to carry out homeland security missions is great, it is also replete with dangers. Soldiers are not police officers, and the danger is always present that they will use force in a manner that is inappropriate in the domestic context.

This issue of Connections is designed to look at how a number of states are meeting these challenges. The authors examine how Austria, Bulgaria, Germany, Hungary, Italy, the United Kingdom, and the United States have approached the issue of the employment of military forces in domestic security. This collection of essays offers readers the opportunity to compare and contrast these experiences and the lessons they offer for future contingencies involving the employment of military force in support of civil authorities.

These countries have different traditions of using military forces domestically; they have different national security strategies; and they have different perceptions of the level of threat to their domestic security. Each nation approaches these issues in a different manner, reflecting their unique histories and the status of the armed forces in the respective states. This collection examines how these states may choose to employ

* Dr. John L. Clarke is a Professor of Leadership, Management, and Defense Planning at the George C. Marshall Center in Garmisch-Partenkirchen, Germany. 
military force in support of a range of homeland security missions, with particular emphasis on defending against potential terrorist attacks.

These missions include the protection of critical infrastructure, border and transportation security, domestic counterterrorism, protection against catastrophic threats, and military civil support. Civil support includes how military forces may aid law enforcement authorities and provide assistance during periods of crisis or other key events.

Many of the military forces profiled here have extensive experience in performing these domestic tasks. The lessons learned from their experiences may serve to help other states' armed forces that are confronted with a similar range of tasks. These essays provide a basis for examining those lessons.

Military forces in Europe and the U.S. have made and continue to be capable of making major contributions to homeland security. The benefits of these future contributions must be carefully balanced with the costs - in terms of both resources and opportunities - of engaging military forces whose primary mission remains the defense of the country. 